\title{
Use of a severity indicator as a predictor of the use of hepatic transplantation resources*
}

\author{
Utilização de indicador de gravidade como fator preditivo \\ do uso de recursos em transplante hepático \\ Utilización de indicador de gravedad como factor predictivo \\ del uso de recursos en trasplante hepático
}

Flavia Regina Cocuzza das Eiras' ${ }^{1}$ Antonio Pires Barbosa ${ }^{1}$, Eliseth Ribeiro Leão², César Augusto Biancolino ${ }^{3}$

How to cite this article:

Eiras FRC, Barbosa AP, Leão ER, Biancolino CA. Use of a severity indicator as a predictor of the use of hepatic transplantation resources. Rev Esc Enferm USP. 2016;50(4):578-584. DOI: http://dx.doi.org/10.1590/S0080-623420160000500006

\footnotetext{
* Extracted from the dissertation "A utilização do indicador de gravidade MELD (Modelo para Doenças Hepáticas Terminais) como fator preditivo do uso de recursos de apoio em Unidade de Transplante Hepático", Universidade Nove de Julho, 2014.

${ }^{1}$ Universidade Nove de Julho, São Paulo, SP, Brazil.

${ }^{2}$ Hospital Israelita Albert Einstein, Instituto de Ensino e Pesquisa, São Paulo, SP, Brazil.

${ }^{3}$ Universidade CEUMA, São Luís, MA, Brazil.
}

\begin{abstract}
Objective: To evaluate the use of a severity indicator for end-stage liver disease as a predictor of resource use in a teaching hospital in São Paulo. Method: Descriptive, retrospective study, classifying independent variables in seven key dimensions: identification/risk rating; length of stay/use of advanced life support; imaging; clinical analysis; special procedures; blood products in the intensive care unit; and in the operating room. The frequencies were analyzed by linear regression analysis of variance to detect relevance due to the dependent variable (severity indicator) in 76 cases seen in 2013. Results: Among the variables studied, those that presented relevance due to the functional risk score were laboratory measurements of bilirubin, amylase, transaminase, blood count, creatine phosphokinase $(\mathrm{p}<0.05)$, hemotherapy procedures fresh frozen plasma $(\mathrm{FFP})$ and platelet concentrate $(\mathrm{p}<0.05)$, and Doppler echocardiography image $(p<0.07)$. Conclusion: Given the results/objective of this study, it is concluded that the indicator presents a potential predictive capability in the use of postoperative resources of liver receptors in the size, clinical analysis, images and hemotherapy dimensions.
\end{abstract}

\section{DESCRIPTORS}

Liver Transplantation; Patient Acuity; Health Management; Health Resources; Perioperative Nursing. 


\section{INTRODUCTION}

With the evolution of healthcare skills and the incorporation of new technologies and knowledge over the past 30 years, the approach of conditions of greater severity and criticality of patients have also changed radically. Clinical conditions that virtually sealed the death prognosis currently have new therapeutic approaches that ensure longer survival and resolution of various conditions of extreme severity. For example, in end-stage liver failure, a severe medical condition that usually affects patients with chronic or acute liver disease, as in acute fulminant hepatitis ${ }^{(1)}$, liver transplantation became a therapeutic alternative of great effectiveness, affecting survival and improving quality of life $\mathrm{e}^{(2)}$.

To enable the care of these worsening health conditions, hospitals have undergone major transformations in their physical infrastructure and in personnel qualification. The management of end-stage liver failure demands the development of specific skills from the care staff, from both the medical-surgical point of view and the nursing process ${ }^{(2)}$, and requires the availability of therapeutic resources, techni$\mathrm{cal}$ and administrative support. Issues related to the existence of appropriate technologies, maintaining low risk contamination environments and the development of logistics processes for selection and collection of organ and tissue started to dominate the routine of specialized units' managers ${ }^{(3)}$.

Health systems, on the other hand, with the introduction and success of these procedures, have faced dilemmas related to the provision of resources for their implementation and funding of the necessary structures and processes $^{(4)}$. In Brazil, this care is organized, especially, in the most advanced centers of medical training and excellence private hospitals. The former, by vocation and principle, are organized in large teaching hospitals, of tertiary reference and specialized in the Unified Health System (SUS, as per its acronym in Portuguese). The latter are a group of hospitals, including philanthropic ones, funded by the complementary/supplementary healthcare system $^{(5-6)}$. However, despite the movements of search for equity and access proposed by the SUS implementation, the organization of transplants and prioritization criteria planning run into very specific dynamics, namely, which patients would benefit from the procedures, how to evaluate the inclusion of certain medical conditions, what elements and resources will be needed to implement the procedures and, especially, what sources will fund the interventions. In order to respond to these premises, three routes were constituted for the organization of procedures: a) the implementation of a vigorous public program for performing transplantation of several organs $s^{(5)}$; b) the inclusion of some types of interventions in the list of procedures that have their funding guaranteed by private health plans ${ }^{(7)}$; and c) routine search of legal aid for the performance of procedures not covered by health plans or toward the change of patient admission criteria to public programs ${ }^{(8)}$. Such paths imply in the need for hospital management organization that serve these patients in order to provide greater operational efficiency and effectiveness ${ }^{(9)}$.
For the liver transplantation procedure to be feasible, a number of conditions must be met such as suitable organ preservation, donor/receptor blood compatibility correlation, the existence of safety and provision of technical resources and people trained in liver removal and implant processes, and availability of materials and drugs essential for maintaining the immediate postoperative phase. In hospitals, physical, technological, human and logistics resources should be available for use at any time, enabling the development of procedures in a timely manner. Examples of these resources are: the availability of beds for care to critical pre - and post-transplantation stages in intensive care units (ICU); large surgical units to collect and implant organs; recovery units to prevent the occurrence of infections (due to the poor immunity of patients); hemotherapy services specialized in the disposal of blood products; laboratory and medical imaging diagnostic units, to assess biochemical, serological and haematological profiles, as well as anatomical and functional structures; and systems for monitoring and preserving vital functions of the receptors ${ }^{(10-11)}$. These and other resources are the organization's responsibility in terms of management and logistics. Their provision presupposes knowledge of these characteristics and the resources to be allocated, which is the reason why studying them can be useful in organizing more assertive and problem-solving care $^{(12)}$, as well as checking for any predictive tool that can assist in the adequate provision without spending or neglecting resources.

According to some scholars ${ }^{(13)}$ "liver transplantation has been used as a therapy for end-stage liver diseases since the 1980s, after its approval by the National Health Institute of the United States of America (USA) in 1983 and, consequently, there was a mortality increase in the waiting lists of transplantation centers in general". The high mortality rate in the waiting list for the procedure led to the development of strategies to reduce it. One was the change in the queue handling criteria, which until mid-2003 (USA) and 2006 (Brazil) occurred in chronological order of registration and started using the MELD score (Model for End-Stage Liver Disease), a mathematical model for predicting risk of death established from clinical and laboratory parameters, whose main characteristic is to predict the survival of $\mathrm{pa}^{-}$ tients in the first three months after placement of percutaneous intrahepatic portosystemic shunt (TIPS) ${ }^{(13)}$. With the implementation of the MELD, there was a revision in practices, in order of selection of potential receptors and implementation of planning tools that enable a reasonable degree of predictability in the practice ${ }^{(14)}$. However, the use of the score does not elaborate the estimated use of support resources that the organization shall provide for the effective maintenance of the surgery success.

The use of information about the care production of a given unit, its characteristics, the resources necessary to the preservation of safe and quality patient care are basic elements for planning the operation of the services that an organization makes available to its users. As a result, health professionals involved in these activities should take advantage of knowledge that come from evaluation of these and 
epidemiological profiles of their target populations to size structures, design processes, estimate human resources and their consequent qualifications and establish performance indicators/standards to monitor these results ${ }^{(15)}$.

The objective of this study, therefore, was to characterize liver transplantations performed in 2013 and check whether the MELD severity indicator of the receptors can set a predictive element for the use of diagnostic, therapeutic and critical support resources in liver transplantation units.

\section{METHOD}

\section{STUDY TYPE}

This is a descriptive exploratory retrospective study, with a quantitative approach ${ }^{(16)}$.

\section{LOCATION}

The study was conducted in the ICU of the gastroenterology department of a public teaching hospital. This is a tertiary/quaternary complexity hospital, of especial size and reference in the treatment of various diseases. The hospital complex has 970 hospital beds, and from these, 94 beds are used for intensive care, divided into nine units of different specialties, with different physical dimensions, characteristics and routines. The study was conducted in the ICU of the digestive surgery department with beds for patients of general and gastric surgery, liver transplantation and those with complications of advanced liver disease. During the study period, in January and February 2013, 12 active beds were considered, and in the remaining months, eight beds remained active due to a structural renovation.

\section{STUdY SAMPLE}

The sample consisted of 70 patients submitted to liver transplantation in 2013; of whom six underwent retransplantation in the unit. One of the records was excluded for not being available in the medical records department, and its data were recovered from the electronic registration system. Thus, data were collected indirectly by the researchers, i.e., by observing the information recorded in the medical records.

\section{Data COLLECTION}

Initially, the researchers made a list of all patients who were submitted to the procedure in 2013 and who remained in the ICU during the postoperative period. Their records were requested and collected from the medical file division, after authorization of the permanent education service and delivered to the researchers for collection of information regarding the set of research interest data.

The research instrument was divided into seven data collection dimensions, which constituted the analysis model proposed by the researchers of this study, and whose variables were derived from the specialized literature ${ }^{(16-17)}$ and the transplantation protocol adopted by the institution. All dimensions contained a sequential ordinal number of the liver transplantation procedure and the hospital general record identifier (RGHC).
In the first dimension, the researchers collected data on sex, age, diagnosis of liver disease, functional MELD on the day of transplantation, corrected MELD for the same day, length of stay in ICU, type of donor (deceased or living) and blood type.

In the second dimension, called length of stay, admission/discharge date from the ICU, reason for the ICU discharge (ward/death), date of admission/discharge from the ward, reason for the ward discharge (house/readmission in the ICU/death) and date of transplantation were collected.

In the third dimension, data related to imaging tests were collected, such as: abdominal/renal ultrasonography, computed tomography (CT) of the abdomen/pelvis, CT scan of the head, other imaging tests or procedures (TIPS, bone scintigraphy and others), $\mathrm{x}$-rays, magnetic resonance imaging, transthoracic/esophageal echo-doppler, transcranial doppler and liver/abdominal and renal doppler.

In the fourth dimension, the data for laboratory tests commonly used in the unit were recorded, such as: total bilirubin and fractions, creatinine, amylase, lactate, functional enzymes, including gamma-glutamyl transpeptidase (Gamma-GT), glutamic-oxaloacetic transaminase (GOT), glutamic-pyruvic transaminase (GPT); in addition to the thromboplastin time, prothrombin time, platelet, factor V, blood count, creatine kinase (CKMB), Jackson Pratt drain hematocrit (JP), fibrinogen, ammonia and pathological examinations.

The fifth dimension recorded the data relating to special procedures such as slow flow hemodialysis (estimated in hours), extended hemodialysis (estimated in procedures), surgical re-approach, retransplantation and catheter placement for measurement of intracranial pressure (ICP).

In the sixth dimension, related to the necessary hemotherapy procedures and interventions in the ICU environment data were collected on the use of concentrated red blood cells $(\mathrm{CH})$, fresh frozen plasma (FFP), criocepted, platelets and platelets apheresis. The seventh dimension proceeded to collect the same data of the sixth in other critical environment of the care process, i.e., the operating room where the transplantation was performed.

\section{DATA ANALYSIS}

The collected data were organized in an Excel database and the frequencies of events were obtained. The purpose was to correlate the diagnostic and values of MELD on the day of transplantation in order to observe the use of distinctive resources according to the severity of the patient. After the individual analysis of each chart for completeness of the items related to the dimensions, the data were analyzed statistically using the STATA ${ }^{\mathrm{TM}} 12.1$.

Data analysis was conducted by means of a statistical method based on multivariate linear regression for analysis of variance (ANOVA) of the seven dimensions of components studied, namely: sex, age and clinical data of the patient undergoing the procedure; length of hospital stay for transplantation and use of clinical support resources; imaging diagnostic tests; laboratory tests; execution of 
special interventional procedures; use of blood products in the operating room and in the post-surgical ICU.

Descriptive statistics were prepared with mean, standard deviation and percentage calculations. The ANOVA, which was the basis for inferential statistics, considered a significance level of $\mathrm{p}$-value inferior or equal to 0.05 , for a $95 \%$ confidence interval among the data found. In addition, correlation analyses were made using Pearson's coefficient. There was an attempt to take into account the correlations between variables according to the MELD score observed for the purpose of identifying its deterministic capacity depending on the model ${ }^{(16)}$.

\section{ETHICAL ASPECTS}

The research project was submitted to the Research Ethics Committee of the studied hospital. It was approved and registered at Plataforma Brasil under the CAAE certificate number 35385514.1.0000.0068.

\section{RESULTS}

The sample was made up of 70 patients, involving 76 liver transplantation procedures (six patients were retransplanted for different needs). Of this sample, 37 (48.68\%) patients were women and $39(51.32 \%)$ were men. The age ranged between 11 and 80 years old, with the majority (63\%) of adults aged between 41 and 70 years old.

The average length of stay of patients in the postoperative ICU ranged from one to 76 days, with a mean of 10.05 (SD - 12.40) days. The mortality rate was 14 patients $(18.42 \%)$ and rehospitalization in the ICU was 17 patients
(22.37\%). Analysis of the MELD severity indicator of patients who died during the period ranged from 12 to 44 on functional assessment (mean of 28.92), and between 22 and 44 on the corrected score (mean of 33.28).

The assessment of the existence of primary diseases or conditions associated with liver failure (frequency distribution of diseases in relation to the quantity of operated patients) demonstrated the occurrence of more than one diagnosis of a hepatic pathological condition. From the total number of prospected charts (76), 39 patients (51.31\%) had one liver disease; 31 (40.79\%) had two; and six (7.90\%) had three concurrent liver diseases.

The primary or associated diseases observed in the sample studied that stood out include: autoimmune hepatitis, primary biliary cirrhosis, cryptogenic cirrhosis, nonalcoholic steatohepatitis or NASH syndrome, alcoholic liver disease (OH cirrhosis), hepatitis $\mathrm{B}$ cirrhosis $(\mathrm{HBV})$, hepatitis $\mathrm{C}$ cirrhosis (HCV), Budd-Chiari syndrome, hepatocellular carcinoma (HCC), chronic kidney disease (CKD), Caroli disease, hepatic artery thrombosis, primary graft dysfunction, and fulminant hepatic failure.

There were 36 procedures of postoperative surgical re-approach, and 11 patients required a new procedure, eight required two surgical procedures and three patients underwent three surgeries for various reasons and postoperative complications.

A preliminary processing stage of the system data was performed to identify the items that had statistical significance within the proposed limits in each measured dimension and to reprocess the data with the exclusion of items that did not present significance, as per Table 1 .

Table 1 - Regression table: F test, R² and coefficients of the adopted model - São Paulo, SP, Brazil, 2013.

\begin{tabular}{|c|c|c|c|c|c|c|}
\hline Number of observations & & & 76 & & & \\
\hline$F(8,64)$ & & & 9.13 & & & \\
\hline Prob $>F$ & & & 0 & & & \\
\hline R-squared & & & 0.5331 & & & \\
\hline Adjusted R-squared & & & 0.4747 & & & \\
\hline MSE Root & & & 8.2387 & & & \\
\hline MELD Func $\sim X$ & Coefficient & Standard Error & $\mathrm{t}$ & $P>|t|$ & {$[95 \%$} & [Confidence] interval \\
\hline Echo-doppler & 2.938627 & 1.598758 & 1.84 & 0.071 & -0.2552583 & 6.132513 \\
\hline Total bilirubin & 6.680418 & 1.752163 & 3.81 & 0 & 3.18007 & 10.18076 \\
\hline Amylase & 0.7152575 & 0.3020507 & 2.37 & 0.021 & 0.1118419 & 1.318673 \\
\hline TGO & -5.686165 & 1.612922 & -3.53 & 0.001 & -8.908347 & -2.463983 \\
\hline CC platelets & 0.7938229 & 0.2400352 & 3.31 & 0.002 & 0.3142975 & 1.273348 \\
\hline Blood cell count & -1.161858 & 0.3109213 & -3.74 & 0 & -1.782994 & -0.5407209 \\
\hline Creatine kinase & -1.096891 & 0.3291019 & -3.33 & 0.001 & -1.754347 & -0.4394344 \\
\hline Fresh frozen plasma ICU & 0.4570406 & 0.1732212 & 2.64 & 0.01 & 0.1109914 & 0.8030897 \\
\hline _cons & 18.1293 & 1.688436 & 10.74 & 0 & 14.75626 & 21.50234 \\
\hline
\end{tabular}

$\mathrm{F}=$ Joint significance test of the dimensions evaluated by the model.

Prob $>\mathrm{F}=$ Probability of the model to overcome the joint significance test.

$\mathrm{R}^{2}=$ explanatory power of the multiple linear regression model.

$\mathrm{R}^{2}$ adjusted = explanatory power of the multiple linear regression model without the dimensions that present collinearity.

MSE Root $=$ Estimate of the standard deviation of the multiple linear regression model.

MELD = Model for End-Stage Liver Disease.

Source: Prepared by the authors. 
The explanatory power of the model was given by $\mathrm{R}^{2}$, which is equal to 0.5331 , i.e., the variables explained in $53 \%$ the predictive ability of the MELD score in relation to the execution of some specific diagnostic and therapeutic procedures. It is relevant to note the fact that when this methodology is used for evaluating the models with the ANOVA, the explanatory power is acceptable with $\mathrm{R}^{2} \mathrm{ex}^{-}$ ceeding $0.32^{(16)}$. The MSE root considers the standard deviation of the estimator, i.e., it is the similar measure to the standard deviation of the sample, and the reference values of the calculated estimator.

\section{DISCUSSION}

According to the literature ${ }^{(14,17)}$, transfusion of more than six units of concentrated red cells has been related to reduced survival following liver transplantation. As observed in the sample studied in relation to this finding, of the 14 deaths in the sample, only two patients did not use this number of units or more than this. The minimum amount of concentrated red blood cells in patients who progressed to death was five and a maximum of 25 units. Only these 14 patients used 165 red blood cell units, 151 fresh frozen plasma units, 161 of criocepted, 163 units of platelets and one platelet apheresis.

In the linear regression table, with respect to the $\mathrm{F}$ test, the joint statistical significance where p-value is equal to zero, it was found that the variables and dimensions included in the model explained the dependent variable, which implies the assumption of its deterministic character.

Another fact observed was that, despite the medical justification for the application of the MELD indicator correction (corrected) for certain medical conditions, there was no statistical significance of the use of this indicator in predicting the use of support resources. This observation goes against the arguments of other authors ${ }^{(18-19)}$, who apply the concept to anticipate the procedure in cases of extreme severity.

Data analysis showed that the laboratory bilirubin, amylase, transaminase, blood count, and CK-MB tests and the hemotherapy procedures fresh frozen plasma (FFP) and platelet concentrates presented significant variations depending on the MELD functional score values statistically significant at the $5 \%$ level, and the imaging echo-doppler level of $7 \%$. From these items, the main positive correlations were related to the number of bilirubin and amylase dosage of postoperative examinations performed, the number of diagnostic procedures by Doppler echocardiography, the use of fresh frozen plasma units in the ICU and platelet concentrate units in the operating room. On the other hand, the main negative correlations observed were related to the number of GOT and CK-MB enzymes and blood counts performed postoperatively. This may mean that patients with higher MELD values may require a larger volume of tests showing positive correlations and lower volume of those with a negative correlation.

The classification by dimensions, according to the characteristics defined by the model with the application of linear regression and analysis of variance, allowed the validation of the dimensions on the use of medical laboratory and imaging tests, and the use of blood products in the ICU and operating room with the detection of some procedures specifically affected by the relative indicator MELD number within the dimensions to which they were related. Among these, when evaluating the predictive potential of using the MELD indicator, it was found that in relation to the dimension of laboratory tests commonly used in these patients, bilirubin and amylase dosage procedures, essentially linked to the excretory function of the transplanted liver, showed a significantly important positive change, confirming the predictive ability of the model evaluated. On the other hand, the negative correlation of the other variables in this dimension suggests that patients with higher scores will require a smaller volume of dosages of functional enzymes (GOT, CK-MB) and blood counts postoperatively.

Similarly, the use of diagnostic imaging procedures, with the execution of Doppler ultrasound for evolutionary monitoring of the liver transplantation receptor, was presented as a variable where the score shows a predictive ability above the estimated confidence interval.

Regarding the use of blood products, the sixth and seventh dimensions in the ICU and in the operating room, respectively, the score also presented a predictive ability of its use in the studied patients, corroborating what was described by other authors ${ }^{(14,17,19)}$.

In contrast to a study developed in the $\mathrm{UK}^{(20)}$, this study sought to assess the correlations between dimensions and variables according to their degree of dependence, making use of the analysis of variance, which allows for measuring the relationship between elements that are part of the dimensions and other variables. Using logistic regression as a statistical technique, the authors of that study identified MELD correlations with ICU length of stay in the post-transplantation and the TISS indicator (Therapeutic Intervention Scoring System), and a consequent increase in care costs for transplantation patients. In addition, they noted a significant increase with a strong concentration in patients who developed renal complications or who required retransplantation ${ }^{(20)}$. In the present study, the findings indicate apparently no significant variation of this item in relation to the needs for support resources.

Another important study in Texas, also with use of multivariate analysis, on the correlations observed regarding the use of resources in liver receptors, showed that the indicator has predictive ability of its use in medicine/pharmacy, clinical laboratory, radiology, dialysis and physiotherapy, which this study partially corroborates ${ }^{(21)}$. In the studied unit and period, it should be noted that, however, the records were not evaluated on the use of drugs and physiotherapy procedures.

Regarding the dimensions of identification and characterization of the patient, length of stay in critical care units and special procedures of technology base, the model allowed verification of low competence using the MELD indicator of liver disease severity in predicting the use of resources. This observation is suggestive that the technology base of advanced life support available in the studied ICU is adequate to meet the current demands of patients undergoing liver transplantation. Similarly, sizing human resources 
devoted to the care of these patients seems to be insufficient to give continence to the needs. Such statements meet the regulatory proposals of the activities related to the procedure $^{(9,11)}$ and the needs of implementation programs regulating risk control and performance of professions involved in the specifics of this form of care ${ }^{(12,18-19)}$.

The nurse is responsible for managing the care provided to patients and families and performs care, administrative, teaching and research activities, which are crucial to the success of liver transplantation. Therefore, it is very important to develop research and/or use their results to support clinical practice using and creating new evidence ${ }^{(22)}$. Nurses are also responsible for the care of transplantation candidates and receptors and for applying the systematization of nursing care at every stage of the transplantation process of organ and tissue to receptors and their family, including pre - and post-transplantation (outpatient) and transplantation (in-hospital) follow up ${ }^{(23)}$. The findings of this study are therefore of particular importance because they combine the MELD assessment not only to their predictive ability of survival and its consequences in the healthcare plan, but - and thus constituting one of the first studies in this area - also point its usefulness in managing the necessary resources and appropriate decision making, which also extends to the multidisciplinary team. This concept goes against the triple aim that seeks the best practices for the best individual care, improving the health of populations and the optimization of health-related costs ${ }^{(24)}$.

Among the limitations that the study presents, it is worthy mentioning the non-availability of segregated data of laboratory tests performed in the operating environment that occur in the absence of management structure that allocates the data to the corresponding unit; and its implementation in a single transplantation center, considered a national reference research center, which does not necessarily imply the assumption that such results will be seen in other centers. In addition, the limitation of the study period in a specific year, with a limited number (although statistically significant) of case studies does not allow generalization of the concept brought by the model for other periods, if we take as principles the knowledge evolution that the center inserts in the community to which it is part of and the introduction of new technologies and approaches to the problem.

To overcome these limitations, and as a suggestion for future studies, the model should be extended to more periods in the studied unit, including the use of other important resources in the care provided, such as the analysis of laboratory tests performed in the operating room. In addition, it should be replicated in other centers of the country, where the procedure is performed.

\section{CONCLUSION}

Given the results obtained and considering the main objective of this study, it can be concluded that the MELD indicator for severity of end-stage liver disease has a potential predictive ability for the use of resources necessary for post-operative treatment of patients undergoing liver transplantation. The higher the MELD severity, the greater the use of post-operative resources of liver receptors as regards clinical tests (especially tests related to the excretory function of the transplanted liver - bilirubin and amylase), imaging (Doppler) and blood therapy (fresh frozen plasma in the ICU and platelet concentrate in the operating room). However, it can also result in a reduction in carrying out unnecessary tests.

Regarding the identified items, their provision and availability for execution at any time of the unit operation may constitute an improvement element of the management process associated with the care and consequent increase of possibilities of therapeutic success.

\section{RESUMO}

Objetivo: Avaliar o uso do indicador de gravidade para doenças hepáticas terminais como fator preditivo do uso de recursos em um hospital-escola de São Paulo. Método: Estudo descritivo, retrospectivo, classificando variáveis independentes em sete dimensões principais: identificação/classificação de risco; tempo de permanência/uso de suporte avançado à vida; exames de imagem; análises clínicas; procedimentos especiais; hemoderivados em unidade de terapia intensiva; e em centro cirúrgico. As frequências foram analisadas por regressão linear com análise de variância para detecção de relevâncias face à variável dependente (indicador de gravidade) em 76 casos atendidos em 2013. Resultados: Dentre as variáveis estudadas, apresentaram relevância em função do escore de risco funcional as dosagens laboratoriais de bilirrubina, amilase, transaminase, hemograma, creatinofosfoquinase $(\mathrm{p}<0,05)$, procedimentos hemoterápicos plasma fresco congelado (PFC) e concentrado de plaquetas $(\mathrm{p}<0,05)$, e imagem Ecodoppler $(\mathrm{p}<0,07)$ Conclusão: Face aos resultados/ propósito do estudo conclui-se que o indicador apresenta potencial capacidade preditiva no uso de recursos pós-operatórios de receptores de fígado nas dimensões, análises clínicas, imagens e hemoterapia.

\section{DESCRITORES}

Transplante de Fígado; Gravidade do Paciente; Gestão em Saúde; Recursos em Saúde; Enfermagem Perioperatória.

\section{RESUMEN}

Objetivo: Evaluar el empleo del indicador de gravedad para enfermedades hepáticas terminales como factor predictivo del uso de recursos en un hospital escuela de São Paulo. Método: Estudio descriptivo, retrospectivo, clasificando variables independientes en siete dimensiones principales: identificación/clasificación de riesgo; tiempo de permanencia/uso de soporte avanzado a la vida; estudios de imagen; análisis clínicos; procedimientos especiales; hemoderivados en unidad de terapia intensiva y en quirófano. Las frecuencias fueron analizadas por regresión lineal con análisis de varianza para detección de relevancias ante la variable dependiente (indicador de gravedad) en 76 casos atendidos en 2013. Resultados: Entre las variables estudiadas, presentaron relevancia en función del score de riesgo funcional las dosificaciones de laboratorio de bilirrubina, amilasa, transaminasa, hemograma, creatinfosfoquinasa ( $\mathrm{p}<; 0,05$ ), 
procedimientos hemoterápicos, plasma fresco congelado (PFC) y concentrado de plaquetas ( $\mathrm{p}<; 0,05)$, e imagen Ecodoppler ( $\mathrm{p}<; 0,07)$. Conclusión: Frente a los resultados/propósito del estudio, se concluyó que el indicador presenta potencial capacidad predictiva en el empleo de recursos post operatorios de receptores de hígado en las dimensiones, análisis clínicos, imágenes y hemoterapia.

\section{DESCRIPTORES}

Trasplante de Higado; Gravedad del Paciente; Gestión en Salud; Recursos en Salud; Enfermería Perioperatoria.

\section{REFERENCES}

1. Meirelles Júnior RF, Salvalaggio P, Rezende MB, Evangelista AS, Guardia BD, Matielo CEL, et al. Liver transplantation: history, outcomes and perspectives. Einstein (São Paulo) [Internet]. 2015 [cited 2015 June 25];13(1):149-52. Available from: http://www.scielo.br/pdf/eins/ v13n1/1679-4508-eins-13-1-149.pdf

2. Ladner DP, Dew MA, Forney S, Gillespie BW, Brown RS, Merion RM, et al. Long-term quality of life after liver donation in the adult to adult living donor liver transplantation cohort study (A2ALL). J Hepatol. 2015;62(2):346-53.

3. Canero TR, Carvalho R, Galdeano LE. Nursing diagnoses for the immediate postoperative period of patients submitted to liver transplantation. Einstein (São Paulo). 2004;2(2):100-4.

4. Carayon P, Gurses AP. A human factors engineering conceptual framework of nursing workload and patient safety in intensive care units. Intensive Crit Care Nurs. 2005;21(5):284-301.

5. Pego-Fernandes PM, Duro Garcia V. Current status of transplantation in Brazil. [editorial]. São Paulo Med J. 2010;128(1):3-4.

6. Brasil. Constituição da República Federativa do Brasil, 1988. Constituição, 1988. Artigo 199. Estabele o direito de liberdade da assistência à saúde à iniciativa privada e define o conceito de complementariedade do setor ao Sistema Único de Saúde [Internet]. Brasilia: Senado Federal; 1988 [citado 2015 maio 25]. Disponivel em: http://www.planalto.gov.br/ccivil_03/constituicao/ConstituicaoCompilado.htm

7. Brasil. Ministério da Saúde; Agencia Nacional de Saude; Associação Médica Brasileira. Diretrizes Clínicas na Saude Suplementar AMB-ANS, 2012 [Internet]. Brasília: MS; 2012 [citado 2015 maio 25]. Disponivel em: http://bvsms.saude.gov.br/bvs/publicacoes/diretrizes_clinicas_2012.pdf

8. Wang DWL, Vasconcelos NP, Oliveira VE, Terrazas FV. Os impactos da judicialização da saúde no município de São Paulo: gasto público e organização federativa. Rev Adm Pública. 2014;48(5):1191-206.

9. Brasil. Ministério da Saúde. Portaria GM/MS n. 1752, de 23 de setembro de 2005. Determina a constituição nos ambientes hospitalares de comissão de transplantes aplicavel à hospitais privados, públicos e filantrópicos com mais de 80 leitos [Internet]. Brasília: MS; 2005 [citado 2015 jun. 14]. Disponível em: http://www.saude.ba.gov.br/transplantes/documentos_tx/GM1752.pdf

10. Brasil. Ministério da Saúde; Agência Nacional de Vigilância Sanitária. Resolução da Diretoria Colegiada (RDC) n. 50, de 21 de fevereiro de 2002. Aprova o Regulamento Técnico destinado ao planejamento, programação, elaboração, avaliação e aprovação de projetos físicos de estabelecimentos assistenciais de saúde [Internet]. Brasília: MS; 2002 [citado 2015 jun. 16]. Disponível em: http://www.anvisa.gov.br/ anvisalegis/resol/2002/50_02rdc.pdf

11. Brasil. Ministério da Saúde. Portaria n. 2600, de 21 de outubro de 2009. Aprova o Regulamento Técnico do Sistema Nacional de Transplante [Internet]. Brasília: MS; 2009 [citado 2015 jun. 16]. Disponível em: http://bvsms.saude.gov.br/bvs/saudelegis/gm/2009/ prt2600_21_10_2009.html

12. Siqueira ILCP, Petrolino HBS, Conishi R. Gerenciamento do Serviço de Enfermagem. In: Vecina Neto G, Malik AM. Gestão em Saúde. Rio de Janeiro: Guanabara Koogan; 2011. p. 231 - 37.

13. Nacif LS, Andraus W, Martino RB, Santos VR, Pinheiro RS, Haddad LB, et al. Adoption of MELD score increases the number of liver transplant. ABCD Arq Bras Cir Dig. 2014;27(3):201-3.

14. Boin IFSF, Leonardi MI, Udo EY, Sevá-Pereira T, Stucchi RSB, Leonardi LS.The application of MELD score in patients submitted to liver transplantation: a retrospective analysis of survival and the predictive factors in the short and long term. Arq Gastroenterol. 2008;45(4):275-83.

15. Escrivão Junior A. Uso da informação na gestão de hospitais públicos. Ciênc Saúde Coletiva. 2007;12(3):655-66.

16. Anderson DR, Sweeney DJ, Williams TA, Camm JD, Cochran JJ. Essentials of statistics for business and economics. 7th ed. Boston: Cengage Learning; 2014.

17. David, AI, Coelho MPC, Paes AT, Leite AK, Guardia BD, Almeida MD, et al. Liver transplant outcome: a comparison between high and low MELD score recipients. Einstein (São Paulo). 2012;10(1):57-61.

18. Cavalcante LP, Ramos IC, Araujo MAM, Alves DMS, Braga VAB. Nursing care to patients in brain death and potential organ donors.Acta Paul Enferm. 2014;27(6):567-72.

19. Rothschild JM, Landrigan CP, Cronin JW, Kaushal R, Lockley SW, Burdick E. The critical care safety study: The incidence and nature of adverse events and serious medical errors in intensive care. Crit Care Med. 2005;33(8):1694-700.

20. Foxton MR, Al-Freah MA, Portal AJ, Sizer E, Bernal W, Auzinger G, et al. Increased model for end-stage liver disease score at the time of liver transplant: results in prolonged hospitalization and overall intensive care unit costs. Liver Transpl. 2010; 16(5):668-77.

21. Washburn WK, Pollock BH, Nichols L, Speeg KV, Halff G. Impact of recipient MELD score on resource utilization. Am J Transplant. 2006;6(10):2449-54.

22. Mendes KDS, Galvão CM. Liver transplantation: evidence for nursing care. Rev Latino Am Enfermagem [Internet]. 2008 [cited 2015 June 16];16(5):915-22. Available from: http://www.scielo.br/pdf/rlae/v16n5/19.pdf

23. Conselho Federal de Enfermagem. Resolução COFEN n. 292/2004. Normatiza a atuação do Enfermeiro na Captação e Transplante de Órgãos e Tecidos [Internet]. Brasília: COFEN; 2004 [citado 2015 jun. 16]. Disponível em: http://www.cofen.gov.br/resoluo-cofen-2922004_4328.html

24. Bisognano M, Kenney C. Buscando o Triple Aim na saúde. São Paulo: Atheneu; 2015. 